\title{
STRATEGI MENGHADAPI STRES SAAT MENYUSUN SKRIPSI PADA MAHASISWA PROGRAM STUDI BIMBINGAN DAN KONSELING UNIVERSITAS MUHAMMADIYAH MAGELANG
}

\author{
Nofi Nur Yuhenita ${ }^{(1)}$, Indiati $^{(2)}$, Astiwi Kurniati ${ }^{(3)}$ \\ Program Studi Bimbingan dan Konseling \\ Fakultas Keguruan dan Ilmu Pendidikan \\ Universitas Muhammadiyah Magelang \\ E-mail: noery.ita@gmail.com
}

\begin{abstract}
Abstrak
Penelitian ini bertujuan untuk mengetahui strategi menghadapi stres (coping stress) saat menyusun skripsi pada mahasiswa BK FKIP UM Magelang yang dilakukan dengan metode kuantitatif dengan jenis penelitian deskriptif. Pengumpulan data dilaksanakan dengan skala strategi menghadapi stres. Mahasiswa BK FKIP UM MAGELANG yang sedang menyelesaikan skripsi mempunyai strategi menghadapi stres berfokus emosi termasuk dalam kategori tinggi dengan persentase sebesar $68,4 \%$ dan strategi menghadapi stres dengan berfokus masalah termasuk dalam kategori sedang dengan persentase sebesar $75,4 \%$.
\end{abstract}

Kata kunci: strategi menghadapi stres, skripsi

\begin{abstract}
This study aims to determine strategies for coping with stress (stress coping) while writing his thesis on student FKIP BK UM Magelang performed with quantitative methods with descriptive research. The collection of data carried out by the scale of the strategy to deal with stress. BK FKIP UM Magelang student who is completing a thesis has focused strategies for coping with emotional stress in the high category with a percentage of $68.4 \%$ and a strategy to deal with stress by focusing issues included in the medium category with a percentage of $75.4 \%$.
\end{abstract}

Key words: facing stress strategies, essay

Info Artikel

Diterima Oktober 2016, disetujui Oktober 2016, diterbitkan Desember 2016 


\section{PENDAHULUAN}

Memasuki universitas acapkali membuat mahasiswa dilanda stres, karena harus memasuki lingkungan yang baru, begitu pula pada saat mahasiswa akan keluar dari universitas atau lulus, karena untuk dapat lulus dari perguruan tinggi dan mendapatkan gelar sarjana, mahasiswa harus menempuh persyaratan salah satunya adalah dengan skripsi/tugas akhir.

Akan tetapi, tidak semua mahasiswa dapat lulus dengan lancar dan tepat waktu, bahkan ada beberapa mahasiswa yang sampai drop-out karena sampai batas waktu masa kuliah yaitu 14 semester mahasiswa tidak mampu untuk menyelesaikan skripsinya. Palmer dan Puri (2006) menuturkan bahwa ujian universitas, seringkali membuat mahasiswa berada pada situasi stres, karena sebagian berpendapat bahwa ujian merupakan ajang untuk pembuktian kemampuan diri. Ditambah lagi dengan tuntutan baik dari keluarga atau diri sendiri yang mengharapkan untuk mendapat hasil memuaskan dari hasil belajar di universitas dan berharap untuk dapat memasuki karir yang bagus setelah lulus.

Kegagalan dalam penyusunan skripsi juga disebabkan oleh adanya kesulitan mahasiswa dalam mencari judul skripsi, kesulitan mencari literatur dan bahan bacaan, dana yang terbatas, serta adanya kecemasan dalam menghadapi dosen pembimbing (Riewanto, 2003). Apabila masalah- masalah tersebut menyebabkan adanya tekanan dalam diri mahasiswa maka dapat menyebabkan adanya stres dalam menyusun skripsi pada mahasiswa.

Stres adalah suatu kondisi adanya tekanan fisik dan psikis akibat adanya tuntutan dalam diri dan lingkungan (Rathus \& Nevid, 2002, h. 142). Stres tidak selalu berdampak negatif pada diri individu, tetapi stres dapat berdampak positif. Stres yang berdampak negatif disebut dengan distress dan stres yang berdampak positif disebut eustress. Senada dengan pendapat diatas, Atkinson (2000) mengemukakan bahwa stres mengacu pada peristiwa yang dirasakan membahayakan kesejahteraan fisik dan psikologis seseorang.

Situasi ini disebut sebagai penyebab stres dan reaksi individu terhadap situasi stres ini disebut sebagai respon stres. Stres diawali dengan adanya situasi yang menekan, kemudian menimbulkan reaksi bagi individu dan individu berusaha untuk menghadapi situasi tersebut. Lazarus dan Folkman (Sarafino, 1998) menuturkan strategi dalam menghadapi masalah (coping) dibagi menjadi dua yaitu emotion-focused coping (koping yang berorientasi atau berfokus pada emosi) dan problemfocused coping (koping yang berorientasi atau berfokus pada masalah). 
Lazarus \& Cohen (Sheri \& Radmacher, 1992) mengidentifikasi stresor ke dalam tiga kategori yaitu:

a. Cataclysmic Stressor

Merupakan kejadian yang terjadi pada beberapa orang atau keseluruhan komunitas dalam waktu yang bersamaan.

b. Personal Stressor (stresor personal)

Stresor personal berpengaruh secara individu, termasuk kejadian seperti gagal ujian, PHK, atau bercerai.

c. Background Stressor (stresor dasar)

Merupakan "pertengkaran sehari-hari" dalam hidup.

Nanang Subekti (2009) dalam artikelnya memaparkan bahwa mengerjakan sebuah skripsi telah menjadikan kebanyakan pelajar atau mahasiswa stres, takut, bahkan sampai frustasi dan ada juga yang nekat bunuh diri. Telah banyak contoh kasus mahasiswa yang menjadi lama dalam penyelesaian studinya karena terganjal dengan masalah tugas akhirnya.

Hasil observasi dan wawancara yang peneliti lakukan terhadap mahasiswa BK FKIP UM Magelang yang sedang menyusun skripsi, banyak mahasiswa yang merasa stres dikarenakan kesulitan yang dihadapi pada saat proses penyusunan. Beberapa mahasiswa BK bahkan ada yang meluapkan keluhan tersebut melalui jejaring pertemanan seperti face-book yang pada intinya menuturkan tentang keluh kesah mereka pada saat proses skripsi, baik masalah motivasi, masalah dosen pembimbing, dan sebagainya.

Widyarini (2008) melakukan penelitian tentang prokrastinasi pada mahasiswa dalam penyelesaian skripsi, dan hasilnya menunjukkan bahwa subjek melakukan prokrastinasi/penundaan pada skripsinya. Prokrastinasi atau penundaan dalam mengerjakan skripsi merupakan bentuk strategi menghadapi masalah berdasarkan emosi (emotionfocused coping). Individu melakukan prokrastinasi untuk menurunkan tingkat stres dengan cepat, akan tetapi hal tersebut tidak akan lama, dan individu akan kembali lagi kepada masalah yang sebenarnya (Palmer dan Puri, 2006).

Menurut Rasmun (2004), strategi menghadapi masalah adalah proses yang dilalui oleh individu dalam menyelesaikan situasi stres, dan merupakan respon individu terhadap situasi yang mengancam dirinya baik fisik maupun psikologik. Berdasarkan pemaparan para ahli, dapat diambil kesimpulan bahwa strategi menghadapi masalah (coping) adalah upaya secara kognitif dan atau behavioral (perilaku) yang dilakukan oleh individu untuk menggerakkan, memandu, memberi tenaga, mengatur emosi, tingkah laku dan orientasi terhadap tuntutan baik internal maupun eksternal sebagai respon individu terhadap situasi stres yang dialami setiap hari dan atau pada kejadian-kejadian khusus. 
Antonovsky (Sheri \& Radmacher, 1992) mengemukakan bahwa setiap strategi menghadapi masalah memiliki tiga komponen utama, yaitu rasionalitas, fleksibilitas, dan melihat lebih jauh.

a. Rasionalitas (rationality)

Didefinisikan sebagai keakuratan, dan keobjektifan dalam menilai situasi atau sumber stres.

b. Fleksibilitas (flexibility)

Didefinisikan sebagai ketersediaan bermacam strategi memecahkan masalah untuk mengatasi sumber stress dan kerelaan untuk mempertimbangkan strategi-strategi tersebut.

c. Melihat lebih jauh (farsightedness)

Merupakan kemampuan untuk mengantisipasi konsekuensi dari bermacam strategi menghadapi masalah.

Lazarus, Folkman dkk (Sarafino, 1998) mengklasifikasikan strategi menghadapi masalah dalam dua tipe yaitu emotion focused coping (SMM berfokus emosi) dan problem -focused coping (SMM berfokus masalah).

a. Emotion-focused coping (SMM berfokus emosi/SMM-E)

Merupakan

strategi

menghadapi masalah dengan menunjukkan kontrol respon emosi dalam menangani situasi stres atau yang berhubungan dengan sumber stres. SMM-E meliputi aspek-aspek sebagai berikut :

1) Menjauhkan diri (distancing), yaitu upaya kognitif untuk melepaskan diri dari situasi stres, atau menciptakan gambaran positif terhadap situasi stres.

2) Pelarian-Menghindar (escape -avoidance), yaitu membayangkan dengan sepenuh hati tentang situasi stress atau mengambil tindakan untuk melarikan diri atau menghindarinya.

3) Kontrol diri (self-control), yaitu usaha untuk mengatur perasaan atau tindakan yang berhubungan dengan masalah.

4) Menerima tanggungjawab (accepting responsibility), yaitu mengakui bahwa diri sendiri memiliki peran dalam masalah tersebut.

5) Penilaian positif (positivereappraisal), yaitu mencoba untuk menciptakan atau menemukan makna positif dari sebuah situasi sebagai pengalaman dalam perkembangan individu atau dengan sentuhan agama/spiritual.

Matheny, dkk (Sheri \& Radmacher, 1992) mengidentifikasi taktik SMM-M meliputi :

1) Monitoring stres (stress monitoring)

2) Penstrukturan (structuring)

3) Ketrampilan sosial (social skill)

b. Problem-focused coping (SMM berfokus masalah).

Strategi menghadapi masalah berfokus masalah (SMM-M) memiliki beberapa aspek yaitu :

1) Pemecahan masalah yang penuh perencanaan (planful problem-solving), yaitu menganalisa situasi untuk 
sampai pada solusi dan kemudian mengambil tindakan langsung untuk mengoreksi masalah.

2) Strategi menghadapi masalah secara konfrontatif (confrontative coping), yaitu upaya secara agresif, mengambil tindakan tegas untuk merubah situasi (walaupun seringkali melibatkan kemarahan atau tindakan beresiko).

3) Mencari dukungan sosial (seeking social support), (dapat SMM-M atau SMM-E) merupakan usaha untuk mendapatkan informasi atau dukungan emosional dari orang lain terhadap situasi stres.

Hasil observasi yang dilakukan, permasalahan dialami mahasiswa BK FKIP UM Magelang saat mengerjakan skripsi adalah kurangnya motivasi internal, segan terhadap dosen pembimbing, kurang bisa membagi waktu, sukar menuangkan ide dan tidak tahu cara menyusun skripsi, nilai mata kuliah banyak yang belum keluar, belum selesai teori, tidak memiliki dana dan fasilitas, kesulitan referensi, dan kesulitan dalam mencari lokasi dan responden penelitian.

Fakta-fakta tersebut menggambarkan bahwa mahasiswa seringkali mengalami kesulitan dalam proses penyusunan skripsi yang menyebabkan mahasiswa berada dalam situasi stres karena banyaknya tuntutan atau situasi menekan baik secara internal ataupun eksternal dan dampak ekstrim dapat memicu kepada tindakan bunuh diri.

Hasil observasi dan wawancara yang peneliti lakukan dengan beberapa mahasiswa BK FKIP UM Magelang yang sedang menyusun skripsi, banyak mahasiswa yang merasa stres dikarenakan kesulitan yang dihadapi pada saat proses penyusunan. Beberapa mahasiswa BK bahkan ada yang meluapkan keluhan tersebut melalui media sosialyang pada intinya menuturkan tentang keluh kesah mereka pada saat proses skripsi, baik masalah motivasi atau masalah dosen pembimbing. Kasus yang terjadi beberapa waktu terakhir menyebutkan bahwa terdapat beberapa mahasiswa BK FKIP UM Magelang yang terbukti melakukan plagiat skripsi.

Berdasarkan fakta dan hasil pengamatan, peneliti berasumsi bahwa terdapat situasi atau sumber stres dan reaksi yang menyertai mahasiswa yang sedang menyusun skripsi serta mahasiswa berupaya untuk menghadapi situasi stres tersebut baik dengan SMM-M atau dengan SMM-E. Oleh karena itu maka penelitian ini dilakukan untuk mengetahui kecenderungan strategi menghadapi masalah stres saat menyusun skripsi pada mahasiswa prodi BK FKIP UM Magelang.

\section{METODE PENELITIAN}


Metode penelitian yang digunakan adalah metode penelitian kuantitatif dengan jenis penelitian deskriptif. Data dari masing-masing variabel dalam penelitian ini berdiri sendiri dan terpisah. Penelitian ini dilaksanakan di Program Studi Bimbingan dan Konseling FKIP UM Magelang pada bulan Februari sampai dengan Mei 2016 dengan subjek dalam penelitian ini adalah sampel dari mahasiswa prodi BK FKIP UM Magelang yang sedang menyusun skripsi. Pengambilan data dilakukan dengan menggunakan skala strategi menghadapi stres. Adapun kisi kisi skala tersebut, sebagai beriku,

Tabel 1.

Kisi-Kisi Penyusunan Skala Strategi Menghadapi Stres Sebelum Uji Coba

\begin{tabular}{|c|c|c|c|c|c|}
\hline $\begin{array}{c}\text { Variabel } \\
\text { Penelitian }\end{array}$ & $\begin{array}{c}\text { Sub } \\
\text { Variabel } \\
\end{array}$ & Indikator & Deskriptor & $\begin{array}{l}\text { Jml } \\
\text { Butir }\end{array}$ & $\begin{array}{c}\text { No } \\
\text { Butir }\end{array}$ \\
\hline \multirow{10}{*}{$\begin{array}{l}\text { Strategi } \\
\text { Menghadapi } \\
\text { Masalah } \\
\text { Stres } \\
\text { (Coping } \\
\text { Stress) }\end{array}$} & \multirow{10}{*}{$\begin{array}{l}\text { Startegi } \\
\text { Menghadapi } \\
\text { Masalah } \\
\text { Berfokus } \\
\text { Emosi } \\
\text { (SMM-E) }\end{array}$} & \multirow[t]{2}{*}{$\begin{array}{l}\text { Menjauhkan } \\
\text { diri } \\
\text { (Distancing) }\end{array}$} & $\begin{array}{l}\text { Upaya kognitif } \\
\text { untuk } \\
\text { melepaskan diri } \\
\text { dari situasi stress }\end{array}$ & 4 & $\begin{array}{c}1,2 \\
21,22\end{array}$ \\
\hline & & & $\begin{array}{l}\text { Mencipatkan } \\
\text { gambaran positif }\end{array}$ & 4 & $\begin{array}{c}3,4, \\
23,24\end{array}$ \\
\hline & & \multirow{2}{*}{$\begin{array}{l}\text { Pelarian- } \\
\text { Menghindar } \\
\text { (escapeavoidan } \\
\text { ce) }\end{array}$} & $\begin{array}{l}\text { Membayangkan } \\
\text { dengan sepenuh } \\
\text { hati }\end{array}$ & 4 & $\begin{array}{c}5,6 \\
25,26\end{array}$ \\
\hline & & & $\begin{array}{l}\text { Tindakan } \\
\text { melarikan diri } \\
\text { atau menghindar }\end{array}$ & 5 & $\begin{array}{c}7,8, \\
27,28, \\
29 \\
\end{array}$ \\
\hline & & \multirow[t]{2}{*}{$\begin{array}{l}\text { Kontrol diri } \\
\text { (self-control) }\end{array}$} & $\begin{array}{l}\text { Mengatur } \\
\text { Perasaan }\end{array}$ & 4 & $\begin{array}{r}9,10 \\
30,31 \\
\end{array}$ \\
\hline & & & $\begin{array}{l}\text { Mengatur } \\
\text { tindakan }\end{array}$ & 5 & $\begin{array}{c}11,12, \\
32,33, \\
34 \\
\end{array}$ \\
\hline & & $\begin{array}{l}\text { Menerima } \\
\text { tanggungjawab } \\
\text { (accepting } \\
\text { responsibility) }\end{array}$ & $\begin{array}{l}\text { Mengakui bahwa diri } \\
\text { sendiri memiliki } \\
\text { peran dalam } \\
\text { masalah. }\end{array}$ & 5 & $\begin{array}{c}13,14 \\
35,36 \\
37\end{array}$ \\
\hline & & \multirow{2}{*}{$\begin{array}{l}\text { Penilaian } \\
\text { positif } \\
\text { (positive } \\
\text { reappraisal) }\end{array}$} & $\begin{array}{l}\text { Menciptakan } \\
\text { atau menemukan } \\
\text { makna positif }\end{array}$ & 4 & $\begin{array}{l}15,16 \\
38,39\end{array}$ \\
\hline & & & Sentuhan agama & 4 & $\begin{array}{l}17,18, \\
40,41\end{array}$ \\
\hline & & $\begin{array}{l}\text { Mencari } \\
\text { dukungan } \\
\text { sosial } \\
\text { (seeking social }\end{array}$ & $\begin{array}{l}\text { Mencari dukungan } \\
\text { secara emosional }\end{array}$ & 3 & $\begin{array}{c}19,20 \\
42\end{array}$ \\
\hline
\end{tabular}




\begin{tabular}{|c|c|c|c|c|}
\hline & support) & & & \\
\hline \multirow{7}{*}{$\begin{array}{l}\text { Strategi } \\
\text { Menghadapi } \\
\text { Masalah } \\
\text { Berfokus } \\
\text { Masalah } \\
\text { (SMM-M) }\end{array}$} & \multirow{2}{*}{$\begin{array}{l}\text { Pemecahan } \\
\text { masalah } \\
\text { dengan } \\
\text { perencanaan } \\
\text { (planful } \\
\text { problem } \\
\text { solving) }\end{array}$} & $\begin{array}{l}\text { Menganalisa } \\
\text { situasi untuk } \\
\text { sampai solusi }\end{array}$ & 4 & $\begin{array}{l}43,44, \\
55,56\end{array}$ \\
\hline & & $\begin{array}{l}\text { Mengambil } \\
\text { tindakan } \\
\text { langsung untuk } \\
\text { mengoreksi } \\
\text { masalah } \\
\end{array}$ & 5 & $\begin{array}{c}45,46, \\
57,58, \\
59\end{array}$ \\
\hline & \multirow[t]{3}{*}{$\begin{array}{l}\text { Konfrontasi } \\
\text { (confrontative } \\
\text { coping) }\end{array}$} & $\begin{array}{l}\text { Upaya agresif } \\
\text { secara positif } \\
\text { untuk merubah } \\
\text { situasi }\end{array}$ & 5 & $\begin{array}{c}47,48, \\
60,61, \\
62\end{array}$ \\
\hline & & $\begin{array}{l}\text { Upaya agresif } \\
\text { secara negatif } \\
\text { untuk merubah } \\
\text { situasi }\end{array}$ & 4 & $\begin{array}{l}49,50 \\
63,64\end{array}$ \\
\hline & & $\begin{array}{l}\text { Mengambil } \\
\text { tindakan tegas }\end{array}$ & 5 & $\begin{array}{c}51,52, \\
65,66, \\
67\end{array}$ \\
\hline & $\begin{array}{l}\text { Mencari } \\
\text { dukungan } \\
\text { sosial (seeking } \\
\text { social support) }\end{array}$ & $\begin{array}{l}\text { Mendapatkan } \\
\text { informasi }\end{array}$ & 5 & $\begin{array}{l}53,54, \\
68,69\end{array}$ \\
\hline & & Jumlah total & 70 & 70 \\
\hline
\end{tabular}

Petunjuk pengisian angket ini, responden diminta untuk memberikan tanda centang $(\sqrt{ })$ pada salah satu pilihan jawaban yang sudah disediakan yang sesuai dengan keadaan dirinya dengan pilihan jawaban yaitu TP (tidak pernah), J (jarang), K (kadang-kadang), SR (sering) dan SL (selalu).

Uji coba instrumen dilakukan terhadap 36 mahasiswa BK FKIP UM Magelang yang sedang menyusun skripsi. Selanjutnya dilakukan uji validitas yang dalam pelaksanaannya, uji validitas skala ini dibantu dengan menggunakan komputer SPSS versi 17. Peneliti menentukan batas korelasi item $r \geq 0,25$ demi tercapainya jumlah item yang seimbang dan mencukupi bagi keperluan penelitian. Setelah dilakukan uji coba instrumen, diperoleh rentangan nilai $r$ yaitu antara $r=0,006$ sampai dengan $r=0,726$ dan item gugur bila nilai $\mathrm{r}$ dibawah 0,25. Item skala yang pada awalnya berjumlah 70 setelah uji coba gugur sebanyak 26 item sehingga berkurang menjadi 44 item, akan tetapi terdapat 4 item yang kembali dipakai meskipun secara konsistensi internal telah gugur yaituitem 7,17,18 dan 27 sehingga skala final strategi menghadapi stres berjumlah 48 . 
Sedangkan reliabilitas menunujuk pada satu pengertian bahwa suatu instrumen cukup dapat dipercaya untuk digunakan sebagai alat pengumpul data karena instrumen tersebut sudah baik (Arikunto, 2002). Setelah dilakukan ujicoba instrumen pada skala strategi menghadapi stres, diperoleh nilai reliabilitas Alpha Cronbach sebesar 0,902 untuk skala sumber stres dan sebesar 0,873 untuk skala strategi menghadapi stres, dimana kedua nilai reliabilitas tersebut dianggap memenuhi syarat karena lebih dari 0,6 dan hampir mendekati 1 .

Teknik analisis data yang digunakan dalam penelitian ini secara umum adalah analisis deskriptif terhadap data kuantitatif atau biasa disebut dengan analisis data deskriptif kuantitatif. Analisis deskriptif kuantitatif yang digunakan yaitu menggunakan teknik frekuensi, persentase, mean, standar deviasi, dan

grafik-grafik penyajian data yang mendukung hasil penelitian.

SMM dalam penelitian ini, individu akan dikategorikan menjadi tiga jenjang yaitu SMM-Emosi berkategori rendah, sedang, tinggi dan SMM-Masalah berkategori rendah, sedang, dan tinggi karena pada dasarnya individu menggunakan dua Strategi Menghadapi Masalah tersebut. Merujuk pada penjelasan Syaifuddin Azwar (2010) berikut adalah pengkategorian SMM dalam penelitian ini :

1. Menentukan skor tertinggi dan terendah

2. Menghitung mean ideal (M) yaitu $1 / 2$ (skor tertinggi + skor terendah)

3. Menghitung standar deviasi (SD) yaitu $1 / 6$ (skor tertinggi - skor terendah)

Batas antara kategori tersebut adalah (M+1SD) dan (M-1SD). Lebih jelasnya lagi, kategori tersebut dapat diamati dalam tabel berikut:

Tabel 2.

Kategori Strategi Menghadapi Masalah berfokus Emosi (SMM-E)

\begin{tabular}{|l|l|}
\hline \multicolumn{1}{|c|}{ Batas (Interval) } & \multicolumn{1}{c|}{ Kategori } \\
\hline skor $<(\mathrm{M}-1 \mathrm{SD})$ SMM-E & Rendah \\
\hline$(\mathrm{M}-1 \mathrm{SD}) \leq$ skor $<(\mathrm{M}+1 \mathrm{SD})$ SMM-E & Sedang \\
\hline$(\mathrm{M}+1 \mathrm{SD}) \leq$ skor SMM-E & Tinggi \\
\hline
\end{tabular}

Tabel 3.

Kategori Strategi Menghadapi Masalah berfokus Masalah (SMM-M)

\begin{tabular}{|l|l|}
\hline \multicolumn{1}{|c|}{ Batas (Interval) } & \multicolumn{1}{c|}{ Kategori } \\
\hline skor $<(\mathrm{M}-1 \mathrm{SD})$ SMM-M & Rendah \\
\hline$(\mathrm{M}-1 \mathrm{SD}) \leq$ skor $<(\mathrm{M}+1 \mathrm{SD})$ SMM-M & Sedang \\
\hline$(\mathrm{M}+1 \mathrm{SD}) \leq$ skor SMM-M & Tinggi \\
\hline
\end{tabular}


Keterangan :

$\mathrm{X}=$ skor subyek $; \mathrm{M}=$ mean ideal $; \mathrm{SD}=$ Standar Deviasi

\section{HASIL \\ PENELITIAN \\ PEMBAHASAN \\ Berikut \\ adalah \\ pemaparan hasil penelitian dan pembahasan sekaligus menjawab pertanyaan penelitian tentang bagaimana Strategi Menghadapi Stres saat Menyusun Skripsi pada Mahasiswa BK FKIP UM Magelang.}

\section{Batas Interval Kategorisasi} Strategi Menghadapi Masalah berfokus Emosi (SMM - E)

Berikut adalah langkahlangkah pengkategorisasian SMM-E untuk menemukan batas interval antara kategori rendah, sedang, dan tinggi :

a. Menentukan skor tertinggi dan terendah Jumlah item pada skala SMM-E adalah 27 dengan 5 pilihan jawaban TP (tidak pernah), J (jarang), K (kadang), SR (sering) dan SL (selalu) yang masingmasing memiliki rentangan nilai dari 1 sampai dengan 5 . berdasarkan hal tersebut, maka skor terendah pada skala ini adalah $1 \times 27=27$ dan skor tertingginya adalah $5 \times 27=135$.

b. Menghitung mean ideal (M) yaitu $1 / 2$ (skor tertinggi + skor terendah)Mem $=1 / 2(135+27)=$ 81.

c. Menghitung standar deviasi (SD) yaitu 1/6 (skor tertinggi - skor terendah) $\mathrm{SDem}=1 / 6(135-27)=$ 18

Berdasarkan perhitungan tersebut, maka dalam menentukan kategorisasi SMM-E adalah sebagai berikut

Tabel 4.

Norma untuk batas interval SMM-E

\begin{tabular}{|l|l|}
\hline \multicolumn{1}{|c|}{ Batas (Interval) } & \multicolumn{1}{c|}{ Kategori } \\
\hline skor $<(\mathrm{M}-1 \mathrm{SD})$ SMM-E & Rendah \\
\hline$(\mathrm{M}-1 \mathrm{SD}) \leq$ skor $<(\mathrm{M}+1 \mathrm{SD})$ SMM-E & Sedang \\
\hline$(\mathrm{M}+1 \mathrm{SD}) \leq$ skor SMM-E & Tinggi \\
\hline
\end{tabular}

Berdasarkan norma tersebut, hasil perhitungan diatas kemudian dikonversikan sehingga hasilnya menjadi :

Tabel 5.

Kategori SMM-E

\begin{tabular}{|c|c|}
\hline Batas (Interval) & $\begin{array}{c}\text { Kategor } \\
\mathbf{i}\end{array}$ \\
\hline skor $<(81-1(18))$ atauskor $<(63)$ SMM-E & Rendah \\
\hline
\end{tabular}

Dipublikasikan Oleh: Program Studi Bimbingan dan Konseling Universitas PGRI Yogyakarta 


\section{Batas Interval Kategorisasi}

\section{Strategi Menghadapi Masalah} berfokus Masalah (SMM - M)

Berikut adalah langkah-langkah pengkategorisasian SMM-M untuk menemukan batas interval antara kategori rendah, sedang, dan tinggi :

1) Menentukan skor tertinggi dan terendah

Jumlah item pada skala SMM-M adalah 21 dengan 5 pilihan jawaban TP (tidak pernah), J (jarang), K (kadang), SR (sering) dan SL (selalu) yang masing masing memiliki rentangan nilai dari 1 sampai dengan 5. Berdasarkan hal tersebut, maka skor terendah pada skala ini adalah

Tabel 6.

Norma Untuk Batas Interval SMM-M

\begin{tabular}{|l|l|}
\hline \multicolumn{1}{|c|}{ Batas (Interval) } & \multicolumn{1}{|c|}{ Kategori } \\
\hline skor $<(\mathrm{M}-1 \mathrm{SD})$ SMM-M & Rendah \\
\hline$(\mathrm{M}-1 \mathrm{SD}) \leq$ skor $<(\mathrm{M}+1 \mathrm{SD})$ SMM-M & Sedang \\
\hline$(\mathrm{M}+1 \mathrm{SD}) \leq$ skor SMM-M & Tinggi \\
\hline
\end{tabular}

Berdasarkan norma tersebut, hasil perhitungan diatas kemudian dikonversikan sehingga hasilnya menjadi :

Tabel 7.

Kategori SMM-M

\begin{tabular}{|l|l|}
\hline \multicolumn{1}{|c|}{ Batas (Interval) } & Kategori \\
\hline skor $<(63-1(14))$ atau skor $<(49)$ SMM-E & Rendah \\
\hline $\begin{array}{l}(63-1(14)) \leq \text { skor }<(63+1(14)) \text { Atau }(49) \leq \text { skor } \\
<(77) \text { SMM-E }\end{array}$ & Sedang \\
\hline$(63+1(14)) \leq$ skor atau $(77) \leq$ skorSMM-E & Tinggi \\
\hline
\end{tabular}


3. Data Hasil Penelitian Tentang Strategi Menghadapi Stres Saat Menyusun Skripsi Pada Mahasiswa BK FKIP UM Magelang

Hasil penelitian tentang Strategi Menghadapi Stres ini diperoleh melalui angket berbentuk skala likert yang diberikan kepada para responden, dan hasil perhitungan statistik SPSS skor dari para responden dapat dilihat pada lampiran.

Berdasarkan skor statistik para responden yang dikonversikan dengan norma batas interval yang telah dipaparkan sebelumnya, hasilnya dapat dicermati melalui table dibawah ini

Tabel 8.

Strategi Menghadapi Stres Saat Menyusun Skripsi Pada Mahasiswa BK FKIP UM Magelang

\begin{tabular}{|c|c|c|c|c|c|c|c|c|c|}
\hline \multirow[b]{2}{*}{$\begin{array}{c}\text { No } \\
\text { Subyek }\end{array}$} & \multirow[b]{2}{*}{$\begin{array}{l}\text { Skor } \\
\text { Em }\end{array}$} & \multirow[b]{2}{*}{$\begin{array}{l}\text { Skor } \\
\text { Mas }\end{array}$} & \multicolumn{2}{|c|}{ Kategori } & \multirow[b]{2}{*}{$\begin{array}{c}\text { No } \\
\text { Subyek }\end{array}$} & \multirow[b]{2}{*}{$\begin{array}{l}\text { Skor } \\
\text { Em }\end{array}$} & \multirow{2}{*}{$\begin{array}{l}\text { Skor } \\
\text { Mas }\end{array}$} & \multicolumn{2}{|c|}{ Kategori } \\
\hline & & & $\begin{array}{c}\text { SMM- } \\
\text { E }\end{array}$ & $\begin{array}{c}\text { SMM- } \\
\text { M }\end{array}$ & & & & $\begin{array}{c}\text { SMM- } \\
\text { E }\end{array}$ & $\begin{array}{c}\text { SMM- } \\
\text { M }\end{array}$ \\
\hline 1 & 95 & 80 & sedang & Tinggi & 30 & 116 & 78 & tinggi & tinggi \\
\hline 2 & 111 & 68 & Tinggi & Sedang & 31 & 106 & 69 & tinggi & sedang \\
\hline 3 & 95 & 65 & sedang & Sedang & 32 & 110 & 80 & tinggi & tinggi \\
\hline 4 & 92 & 56 & sedang & Sedang & 33 & 104 & 61 & tinggi & sedang \\
\hline 5 & 108 & 64 & Tinggi & Sedang & 34 & 109 & 70 & tinggi & sedang \\
\hline 6 & 115 & 85 & tinggi & Tinggi & 35 & 95 & 69 & sedang & sedang \\
\hline 7 & 99 & 69 & tinggi & Sedang & 36 & 95 & 56 & sedang & sedang \\
\hline 8 & 111 & 68 & tinggi & Sedang & 37 & 90 & 62 & sedang & sedang \\
\hline 9 & 103 & 76 & tinggi & Sedang & 38 & 116 & 75 & tinggi & sedang \\
\hline 10 & 103 & 68 & tinggi & Sedang & 39 & 112 & 79 & tinggi & tinggi \\
\hline 11 & 91 & 81 & sedng & Tinggi & 40 & 108 & 76 & tinggi & sedang \\
\hline 12 & 107 & 60 & tinggi & Sedang & 41 & 114 & 70 & tinggi & sedang \\
\hline 13 & 95 & 59 & sedang & Sedang & 42 & 109 & 79 & tinggi & tinggi \\
\hline 14 & 104 & 52 & tinggi & Sedang & 43 & 100 & 64 & tinggi & sedang \\
\hline 15 & 106 & 60 & tinggi & Sedang & 44 & 110 & 74 & tinggi & sedang \\
\hline 16 & 91 & 74 & sedang & Sedang & 45 & 119 & 57 & tinggi & sedang \\
\hline 17 & 108 & 62 & tinggi & Sedang & 46 & 116 & 85 & tinggi & tinggi \\
\hline 18 & 101 & 70 & tinggi & Sedang & 47 & 103 & 58 & tinggi & sedang \\
\hline 19 & 109 & 66 & tinggi & Sedang & 48 & 93 & 56 & sedang & sedang \\
\hline 20 & 97 & 61 & sedang & Sedang & 49 & 97 & 76 & sedang & sedang \\
\hline 21 & 119 & 85 & tinggi & Tinggi & 50 & 100 & 59 & tinggi & sedang \\
\hline 22 & 92 & 67 & sedang & Sedang & 51 & 88 & 71 & sedang & sedang \\
\hline 23 & 100 & 56 & tinggi & Sedang & 52 & 106 & 75 & Tinggi & sedang \\
\hline 24 & 110 & 75 & tinggi & Sedang & 53 & 95 & 61 & sedang & sedang \\
\hline 25 & 77 & 46 & sedang & Rendah & 54 & 121 & 71 & Tinggi & sedang \\
\hline 26 & 106 & 61 & tinggi & Sedang & 55 & 109 & 93 & tinggi & tinggi \\
\hline 27 & 94 & 52 & sedang & Sedang & 56 & 83 & 44 & sedang & rendah \\
\hline
\end{tabular}




\begin{tabular}{|l|l|l|l|l|l|l|l|l|l|}
\hline 28 & 124 & 88 & tinggi & Tinggi & 57 & 122 & 95 & tinggi & tinggi \\
\hline 29 & 104 & 58 & tinggi & Sedang & & & & & \\
\hline
\end{tabular}

Berdasarkan table tersebut, kemudian dihitung secara kuantitatif jumlah frekuensi dan persentase masing-masing kategori strategi, yang dapat diamati dalam tabel berikut:

Tabel 9.

Perhitungan Frekuensi dan Persentase Strategi Menghadapi Stres Pada

Mahasiswa

\begin{tabular}{|c|c|c|c|c|}
\hline \multirow{2}{*}{ Kategori } & \multicolumn{2}{|c|}{ SMM-E } & \multicolumn{2}{c|}{ SMM-M } \\
\cline { 2 - 5 } & Frekuensi & Persentase (\%) & Frekuensi & Persentase (\%) \\
\hline Rendah & 0 & 0,0 & 2 & 3,5 \\
\hline Sedang & 18 & 31,6 & 43 & 75,4 \\
\hline Tinggi & 39 & 68,4 & 12 & 21,1 \\
\hline Total & 57 & 100,0 & 57 & 100,0 \\
\hline
\end{tabular}

Pada tabel tersebut, dapat diperoleh pemahaman bahwa hasil penelitian pada mahasiswa BK FKIP UM MAGELANG untuk SMM-E kategori "Rendah" adalah $0 \%$, kategori "Sedang" adalah 31,6\% dan kategori "Tinggi" adalah 68,4\%. Hasil penelitian untuk SMM-M yaitu kategori "Rendah" sejumlah 3,5\%, kategori "Sedang" sejumlah 75,4\% dan kategori "Tinggi" dengan jumlah $21,1 \%$. Berdasarkan hal tersebut, maka dapat diambil kesimpulan bahwa pada saat menggunakan Strategi Menghadapi Stres berfokus emosi (SMM-E) dengan kategori "Tinggi" dan menggunakan Strategi Menghadapi Stres berfokus masalah (SMM-M) dengan kategori "Sedang".

Berdasarkan hasil penelitian yang telah dipaparkan diatas, dan dengan perhitungan statistik sesuai dengan norma yang telah ditentukan, maka strategi menghadapi stres saat menyusun skripsi pada mahasiswa BK FKIP UM Magelang cenderung berfokus emosi dengan kriteria tinggi atau SMM-E "tinggi" dan berfokus masalah dengan kriteria sedang atau SMM-M "sedang". Berdasarkan hal tersebut strategi menghadapi masalah muncul karena adanya reaksi terhadap stres yang disebabkan karena adanya situasi atau kondisi yang menekan baik berasal dari faktor internal maupun eksternal pada saat menyusun skripsi. Adanya sumber-sumber stres yang membuat mahasiswa merasa berada dalam kondisi yang tidak nyaman atau tertekan, membuat mahasiswa berusaha untuk mengatasi atau menghadapi situasi tersebut baik dengan SMM-E, SMM-M ataupun keduanya, karena pada dasarnya, setiap manusia,dalam suatu kondisi stres bisa menggunakan SMM-E atau SMM-M secara bersamaan, hanya 
mungkin dengan kategori yang berbeda.

Hasil penelitian tentang strategi menghadapi stres saat menyusun skripsi pada mahasiswa BK yang peneliti lakukan menyebutkan bahwa mahasiswa saat menyusun skripsi memiliki kecenderungan menggunakan SMM-E yang "tinggi" dan SMM-M yang "sedang". Hasil penelitian sebelumnya yang berkaitan dengan strategi menghadapi stres, dilakukan oleh Hernawati pada tahun 2005 yang berkaitan dengan penyesuaian diri pada mahasiswa tahun pertama yang tinggal di Asrama Putra dan Asrama Putri Kampus IPB Darmaga, dalam menghadapi situasi stres cenderung melakukan strategi problem-focused coping (SMM-M) dibandingkan emotional- focused coping (SMM-E).

Hasil penelitian yang dilakukan oleh Widyarini tahun 2008 yang melakukan penelitian tentang prokastinasi pada mahasiswa dalam penyelesaian skripsi, dan hasilnya menunjukkan bahwa subjek melakukan prokrastinasi/penundaan pada skripsinya. Berdasarkan pemaparan hasil penelitian Widyarini dan hasil penelitian saat ini, terdapat kesesuaian atau relevansi diantara keduanya. Penundaan atau prokrastinasi yang dilakukan oleh mahasiswa saat menyusun skripsi merupakan tindakan yang bersifat emotif, dan diperkuat hasil penelitian saat ini yang menyebutkan bahwa mahasiswa BK FKIP UM
MAGELANG cenderung menghadapi stres dengan SMM- E "tinggi" dan SMM-M "sedang", menjadi salah satu bukti bahwa hal tersebut bukan menjadi suatu hal yang asing dalam lingkungan mahasiswa saat menyusun skripsi, akan tetapi hal tersebut perlu lebih diwaspadai oleh semua pihak yang terkait.

Penelitian yang peneliti lakukan memiliki beberapa keterbatasan, diantaranya sebelum melakukan penelitian, peneliti belum melakukan assessment secara meluas dan mendalam terhadap stres yang dialami oleh mahasiswa jurusan lain saat menyusun skripsi sehingga tidak ada data pembanding. Hasil penelitian ini tidak dapat digeneralisasi, sebab teknik pengambilan sampel tidak menggunakan proportionate stratified random sampling dan hanya menggunakan stratified sampling dimana tidak dilakukan random sehingga tidak memenuhi syarat generalisasi.

\section{KESIMPULAN}

Berdasarkan pembahasan hasil penelitian yang telah dilakukan maka diperoleh kesimpulan bahwa strategi menghadapi stres saat menyusun skripsi pada mahasiswa BK FKIP UM Magelang adalah Strategi Menghadapi Masalah berfokus Emosi kategori "tinggi" dan Strategi Menghadapi Masalah berfokus Masalah kategori "sedang".

Berdasarkan hasil penelitian yang diperoleh, maka saran yang 
dapat peneliti berikan kepada mahasiswa yaitu menghadapi masalah saat menyusun skripsi dengan berfokus emosi bukan merupakan hal yang buruk, akan tetapi juga harus lebih diimbangi dengan berfokus pada masalah skripsi supaya terjadi keseimbangan dan kesinambungan sehingga akan sangat bermanfaat dalam menyelesaikan situasi stres saat menyusun skripsi.

\section{DAFTAR PUSTAKA}

Aldwin, Carolyn.M. (2007). Stress, Coping and Development: An Integrative Perspective (2nd Ed). NewYork: The Guilford Press.

Atkinson, Smith dkk. (2000). Environmental Psychology (4th Ed). Harcout Brace: College Publisher.

Berry, L.M. (1998). Psychology at Work : An Introduction to organization Psychology (2nd Ed). NewYork: Mc Graw Hill.

Frydenberg, Erica. (2008). Adolescent Coping : Advandces in Theory, Research and Practice. London and New York : Roudledge Taylor and Francis Group.

Jonathan Sarwono (2006). Metode Penelitian Kuantitatif dan Kualitatif. Yogyakarta: Graha Ilmu.

Looker, Terry \& Olga Gregson. (2004). Managing Stress (Mengatasi Stres Secara Mandiri) (Haris Setyawati. Terjemahan). London: BACA.
Margono S. (2005). Metodologi Penelitian Pendidikan. Jakarta: Rineka Cipta.

Moh. Nazir. (2005). Metode Penelitian. Bogor : Ghalia Indonesia.

Nana Syaodih Sukmadinata. (2007). Bimbingan dan Konseling dalam Praktek, Mengembangkan Potensi dan Kepribadian Siswa. Bandung: Maestro.

Nasution. (2000). Metode Research (Penelitian Ilmiah). Jakarta: Bumi Aksara.

Rasmun. (2004). Stres, Koping dan Adaptasi: Teori dan Pohon Masalah Keperawatan. Jakarta: Sagung Seto.

Saifuddin Azwar. (2010). Penyusunan Skala Psikologi. Yogyakarta: Pustaka Pelajar. . (2003). Reliabilitas dan Validitas. Yogyakarta: Pustaka Pelajar. .(2002). Metode Penelitian. Yogyakarta: Pustaka Pelajar.

Scott, Carol.J. (2010). Optimal Stress: Living in Your Best Stress Zone. USA : John Willey \& Sons. Inc.

Snyder, C.R (2001). Coping With Stress (Effective People and Procesess). New York : Oxford University Press, Inc. 
Sugiyono. (2008). Metode Penelitian

Kuantitatif, Kualitatif dan $R \& D$. Bandung: Alfabeta.

(2006). Prosedur Penelitian : Suatu Pendekatan Praktik Ed.Revisi VI. Jakarta:

Suharsimi Arikunto. (2007). Rineka Cipta.

Manajemen Penelitian. Jakarta :

Rineka Cipta. 